\title{
Effect of Producer Gas from Redgram Stalk and Combustion Chamber Types on the Emission and Performance Characteristics of Diesel Engine
}

\author{
K. M. Akkoli ${ }^{1}$, N. R. Banapurmath ${ }^{2} \mathbb{D}$, Suresh G ${ }^{3}$, Manzoore Elahi M. Soudagar 4,*(D), T. M. Yunus Khan ${ }^{5} \mathbb{D}$, \\ Maughal Ahmed Ali Baig ${ }^{6}$, M. A. Mujtaba ${ }^{7}$ D, Nazia Hossain ${ }^{8, *(D)}$, Kiran Shahapurkar ${ }^{9}$, Ashraf Elfasakhany ${ }^{10}$, \\ Mishal Alsehli ${ }^{10}$, V. S. Yaliwal ${ }^{11}$ and S. A. Goudadi ${ }^{1}$
}

Citation: Akkoli, K.M.; Banapurmath, N.R.; G, S.; Soudagar, M.E.M.; Khan, T.M.Y.; Baig, M.A.A.; Mujtaba, M.A.; Hossain, N.; Shahapurkar, K.; Elfasakhany, A.; et al. Effect of Producer Gas from Redgram Stalk and Combustion Chamber Types on the Emission and Performance Characteristics of Diesel Engine. Energies 2021, 14, 5879. https:// doi.org/10.3390/en14185879

Academic Editor: Lyes Bennamoun

Received: 11 August 2021

Accepted: 13 September 2021

Published: 17 September 2021

Publisher's Note: MDPI stays neutral with regard to jurisdictional claims in published maps and institutional affiliations.

Copyright: (C) 2021 by the authors. Licensee MDPI, Basel, Switzerland. This article is an open access article distributed under the terms and conditions of the Creative Commons Attribution (CC BY) license (https:/ / creativecommons.org/licenses/by/ $4.0 /)$.
1 Hirasugar Institute of Technology, Belagavi 591236, India; kmakkoli.mech@hsit.ac.in (K.M.A.); sagoudadi.mech@hsit.ac.in (S.A.G.)

2 School of Mechanical Engineering, BVB College of Engineering and Technology, KLE Technological University, Hubballi 580031, India; nrbanapurmath@gmail.com

3 Adama Science and Technology University, Adama 1888, Ethiopia; suresh.guluwadi@gmail.com

4 Department of Mechanical Engineering, School of Technology, Glocal University, Delhi-Yamunotri Marg, SH-57, Mirzapur Pole, Saharanpur 247121, India

5 Department of Mechanical Engineering, College of Engineering, King Khalid University, Abha 61421, Saudi Arabia; yunus.tatagar@gmail.com

6 Department of Mechanical Engineering, CMR Technical Campus, Hyderabad 501401, India; mabaig09@gmail.com

7 Department of Mechanical Engineering, Faculty of Engineering, University of Malaya, Kuala Lumpur 50603, Malaysia; m.mujtaba@uet.edu.pk

8 School of Engineering, RMIT University, Melbourne, VIC 3000, Australia

9 School of Mechanical, Chemical and Materials Engineering, Adama Science and Technology University, Adama 1888, Ethiopia; kiranhs1588@astu.edu.et

10 Mechanical Engineering Department, College of Engineering, Taif University, P.O. Box 11099, Taif 21944, Saudi Arabia; a.taha@tu.edu.sa or ashr12000@yahoo.com (A.E.); m.alsehli@tu.edu.sa (M.A.)

11 SDM College of Engineering and Technology, Dharwad 580002, India; vsyaliwal2000@rediffmail.com

* Correspondence: me.soudagar@gmail.com (M.E.M.S.); bristy808.nh@gmail.com (N.H.); Tel.: +91-98446-65621 (M.E.M.S.); +61-4-8012-3691 (N.H.)

Abstract: The engine performance has been improved by modifying the combustion chamber shape of the diesel engine for dual-fuel operation with liquid fuel and producer gas (PG). The combined effect of gaseous fuel from redgram stalk and combustion chamber type on the emission and performance of blended-fuel of diesel and HOME biodiesel-PG has been investigated. In this experimental study, four varieties of combustion chambers hemispherical (HCC), low swirl (LSCC), dual swirl (DSCC), and toroidal re-entrant (TRCC) were analyzed comprehensively. The results presented that the TRCC configuration with a given nozzle geometry has $9 \%$ improved brake thermal efficiency (BTE) and 10.4\% lower exhaust gas temperature (EGT). The smoke, unburnt hydrocarbon (UBHC), and carbon monoxide (CO) decreased by $10-40 \%$, but a $9 \%$ increase in nitrogen oxides $\left(\mathrm{NO}_{\mathrm{X}}\right)$ emission levels was observed with TRCC. The delay period and combustion period were decreased by $5 \%$ and $7 \%$. The fuel replacement of about $71 \%$ for the diesel-PG combination with HCC and $68 \%$ for the HOME-PG combination with TRCC was achieved.

Keywords: redgram stalk; combustion chamber shape; producer gas; performance; engine emissions

\section{Introduction}

Biomass fulfils different needs of humans as food, fodder, energy, and shelter since ancient days. In the present scenario, biomass-derived fuels for energy applications play a vital role due to their several benefits [1-4]. Studies on biomass showed that biomass was the primary source of energy in rural areas and more than 50\% in the urban areas of India. In rural India, about $70 \%$ of the people depend on farming for their livelihood. 
India has a considerable prospective for bio-derived fuels and agriculture waste which was around 500 million metric tons of biomass per year during the years 2016-17, and the predicted biomass production during the years 2024-2025 will be approximately 1127 million metric tons. As far as biomass energy is concerned, India's Central Electricity Authority (CEA-2017) reports that electricity generation during 2016-2017 was about $7000 \mathrm{MW}$ from agricultural residues, 18,000 MW from forest residues in India. At present, 32\% of primary energy is from biomass in the country. The biomass-based power plant's total installed capacity in India is about $2559 \mathrm{MW}$, and it was observed that energy from agricultural residues and various woody biomasses was found to be about $1800 \mathrm{MW}$ approximately. By 2050, all countries will meet the greenhouse gas reduction targets by utilizing greater renewable energy potential that provides sustainable energy since the estimated world production of biomass is about 146 billion metric tons every year $[5,6]$. Increased use of biomass can mitigate the negativity of energy supply from conventional fuels. Hence, for engine and thermal applications, biomass and biodiesel energy play a role in reducing GHG emissions and providing a solution to energy security and socio-economic issues suitably [7-14].

In this context, the use of biomass for the production of electricity is more appropriate because the simple equipment gasifier can generate the producer gas. Low calorific value producer gas is generated from biomass, and that can be used to run IC (internal combustion) engines to generate electrical or mechanical power. The SI engines can run on producer gas only but the CI (compression ignition) engines cannot run on PG only because of high self-ignition temperature. Therefore, little quantity of liquid fuel (diesel or biodiesel) is used to initiate the combustion. Many researchers reported that diesel engines using producer gas emit lower smoke and $\mathrm{NO}_{\mathrm{X}}$ with little compromise in thermal efficiency [1,15-17]. It was reported that the operation of the engine in dual fuel mode at lower loads causes underutilization of gaseous fuel resulting in lower thermal efficiency and higher $\mathrm{CO}, \mathrm{HC}$ emissions than the operation with diesel [18-22]. Using the producer gas in dual-fuel CI engines will save about $60-80 \%$ of pilot fuel and $100 \%$ fossil fuel if biodiesel is used. Additionally, the diesel/biodiesel-PG dual-fuel engine operation does not require significant engine modifications [23-27].

The highest pilot fuel replacement was achieved for operation with triple fuel or the addition of hydrogen to producer gas, but higher combustion temperature leads to higher $\mathrm{NO}_{\mathbf{X}}$ emissions $[20,28,29]$. Some authors reported using liquefied petroleum gas in dual-fuel diesel engines for optimizing compression ratio (CR) and $\mathrm{NO}$ emissions [30]. Higher CR is more significant in the performance and emissions of the diesel/biodieselPG dual-fuel operation [31]. Further, the addition of hydrogen resulted in improved combustion at higher load conditions [32]. Several researchers reported the use of $\mathrm{CO}$ and $\mathrm{H}_{2}$ mixture similar to PG and studied the performance and emissions. Results of the study showed higher $\mathrm{HC}$ and $\mathrm{CO}$ emissions and lower $\mathrm{NO}_{\mathrm{X}}$ emissions than the operation with diesel $[33,34]$. Some investigators have studied producer gas generated from downdraft gasifiers using various agricultural residue feedstocks in the dual-fuel engine and their effects on the emission and performance characteristics [16,35]. Some literature studies show that gaseous fuels $\mathrm{CH}_{4}, \mathrm{OH}, \mathrm{CO}, \mathrm{H}_{2}, \mathrm{CNG}$, and LPG could be used along with biodiesel/diesel in a dual-fuel operation to investigate the emission and performance characteristics [36-40]. However, literature shows that very few studies are available on the use of producer gas from the agricultural residue as a secondary fuel in dual-fuel diesel engine operation. In these few studies, investigators have used a variety of gasification feedstocks like coir-pitch [24], wood chips [41], corn cobs, pigeon pea stalk [42], coconut shells, and babul wood [43] for gasification. Barriers to using PG for engine application are biomass blockage within gasifiers leading to lower gas generation and converting to tar at higher temperatures which causes stagnant gas and poor performance [44]. Instead of wood chips, the use of biomass from agricultural residue in the form of briquettes will reduce the clogging at the throat [45]. The development of tar depends on the raw material type used and the type of the gasifier but it can be reduced by using a suitable cleaning 
and cooling system [46]. Since the producer gas was derived from agricultural residue, i.e., redgram waste, there is minimal effect on the environment. The residue of the redgram waste after generating the producer gas was used as cattle feed and fertilizer. Hence, there is total utilization of the biomass feedstock without affecting the environment. A literature review shows that diesel engine using PG has improved performance during dual-fuel operation compared to the single fuel with lower smoke and $\mathrm{NO}_{\mathrm{X}}$ emissions [47]. Hence the present work was undertaken to study the effect of PG from redgram stalk agricultural residue and diesel/HOME combination with different combustion chamber shapes. Finally, a comparison of results with the baseline operation was completed.

\section{Materials and Methodology}

\subsection{Fuel Characteristics}

The proximate analysis gives the moisture, volatiles, ash, and fixed carbon by difference according to ASTM standards (D-3172-73 through D-3174-82 and D-3175-82). The ultimate analysis gives the chemical composition of carbon, hydrogen, nitrogen, sulfur, and oxygen (CHNSO) using the $\mathrm{CHN}$ element analyzer. The compositions of the redgram stalk and liquid fuel properties are presented in Tables 1 and 2. The redgram stalk is available in good quantity in the north Karnataka region and is a potential gasifier feedstock. Redgram stalk has suitable characteristics for gasification and gives the quality producer gas to run $\mathrm{CI}$ engines. The redgram stalk briquettes are used in the downdraft gasifier.

Table 1. Properties of liquid fuels [20].

\begin{tabular}{cccc}
\hline Sl. No. & Properties & Conventional Fossil Fuel & HOME Biodiesel \\
\hline 1 & Viscosity at $40^{\circ} \mathrm{C}$ & $4.6(\mathrm{Low})(\mathrm{cst})$ & $5.59(\mathrm{cst})$ \\
2 & Flash point & $56{ }^{\circ} \mathrm{C}$ & $162{ }^{\circ} \mathrm{C}$ \\
3 & HV (higher) & $44.5 \mathrm{MJ} / \mathrm{kg}$ & $35.5 \mathrm{MJ} / \mathrm{kg}$ \\
4 & Specific gravity & 0.829 & 0.869 \\
5 & Density & $829 \mathrm{~kg} / \mathrm{m}^{3}$ & $869 \mathrm{~kg} / \mathrm{m}^{3}$ \\
6 & Type & Fuel & Biodiesel \\
\hline
\end{tabular}

Table 2. Redgram stalk biomass composition $[48,49]$.

\begin{tabular}{cc}
\hline Parameters & Composition Value \\
\hline Moisture & $4.22 \% \mathrm{wt}$. \\
Volatile matter & $82.82 \% \mathrm{wt}$. \\
Fixed carbon & $8.92 \% \mathrm{wt}$. \\
Ash & $4.036 \% \mathrm{wt}$. \\
$\mathrm{C}$ & $49.24 \% \mathrm{mass}$ \\
$\mathrm{H}$ & $5.93 \% \mathrm{mass}$ \\
$\mathrm{N}$ & $3.779 \% \mathrm{mass}$ \\
O & $30.13 \% \mathrm{mass}$ \\
HV (higher) & $16.75 \mathrm{MJ} / \mathrm{kg}$ \\
Density & $502.0 \mathrm{~kg} / \mathrm{m}^{3}$ \\
\hline
\end{tabular}

\subsection{Experimental Setup}

The experimentation was carried out on a single-cylinder, 4-stroke, VCR CI engine test stand, as shown in Figure 1 experimental setup (a) and (b). An eddy current dynamometer was used to measure the load on the engine using the electric bulbs. The rotor rotates with the help of the diesel engine shaft and the voltage is applied to the coil or stator housing. Since such magnetic flux is generated and the rotor cuts off these magnetic fluxes, the eddy current opposite to the change in magnetic flux is generated in the rotor. Therefore, the rotor obtains a reverse force and attempts to reduce the rotational speed of the rotor. However, the torque provided by the diesel engine maintains the speed. This torque is measured by a sensor at the end of the arm on the dynamometer. The gasifier was appropriately connected to the diesel engine. The producer gas was generated in the gasifier of downdraft type and 
fed to the engine. The PG flow rate was measured with a digital venturi meter, and the flow rate of diesel or HOME was measured continuously. The constant speed of the engine at $1500 \mathrm{rpm}$ is maintained by varying the flow rate of pilot fuel operating the regulator. The PG and air are inducted into the engine cylinder and compressed; the pilot fuel is injected to ignite the mixture at the end of the compression stroke. The piezoelectric transducer mounted on the cylinder head was used for measuring cylinder pressure and gas analyzer, and the Hartridge smoke meter for measuring emissions. The specifications of the engine and the gasifier are presented in Table 3.

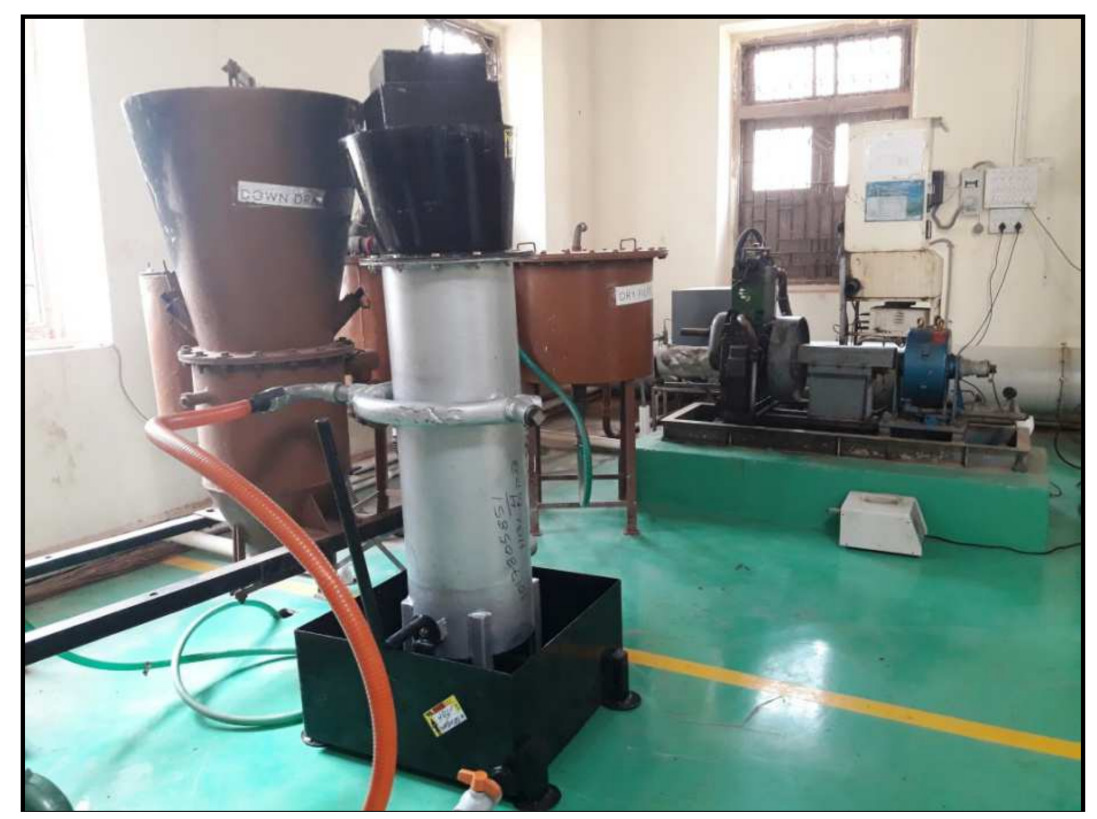

(a)

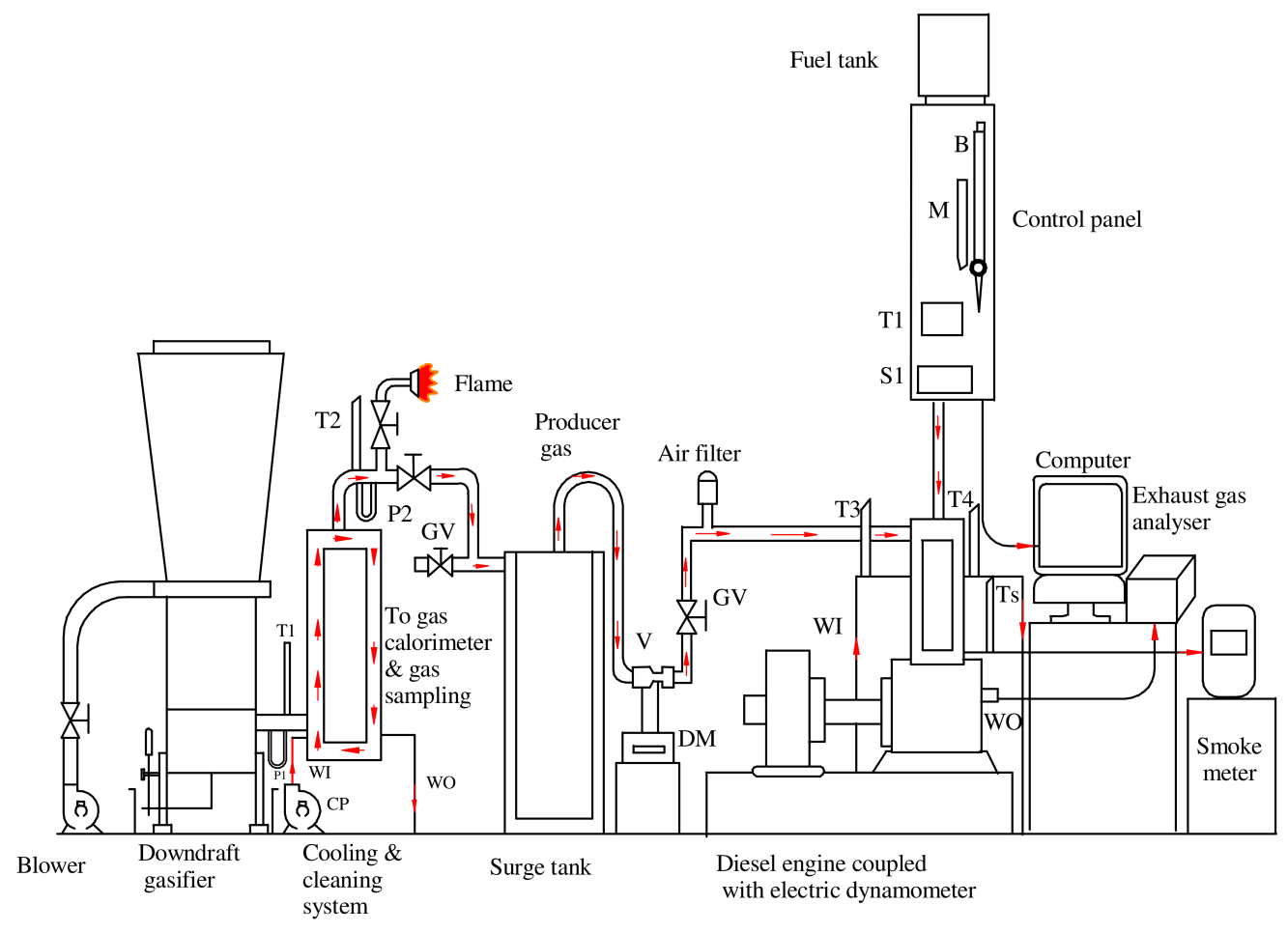

(b)

Figure 1. (a) Gasifier, (b) gasifier-engine setup [48]. 
Table 3. Specifications of engine and gasifier [48].

\begin{tabular}{ccccc}
\hline S1. No. & \multicolumn{2}{c}{ Engine } & Gasifier \\
\hline & Parameters & Specifications & Parameters & Specifications \\
\hline 1 & Engine type & Kirloskar DI, single-cylinder, & Supplier & Harith Avani Technologies Pvt. \\
2 & 4-stroke, diesel engine & Ptd. Bengaluru & $62,735 \mathrm{~kJ} / \mathrm{h}$ and $15 \mathrm{Nm} / \mathrm{h}$ \\
3 & Power & $205-240 \mathrm{bar}$ & Power and gas flow & $19 \mathrm{MJ} / \mathrm{kg}$ \\
4 & Bore & $3.7 \mathrm{~kW}$ & Biomass consumption & $10 \mathrm{~kg} / \mathrm{h}$ \\
5 & Stroke & $87.5 \mathrm{~mm}$ & Hopper capacity & $40 \mathrm{~kg}$ \\
6 & CR & $110 \mathrm{~mm}$ & Efficiency & $75-80 \%$ \\
\hline
\end{tabular}

\subsection{Methodology}

The agricultural residue redgram stalk (RGS) is used for the generation of the producer gas for experimentation. The producer gas derived from redgram stalk is used to run the engine under dual-fuel mode with diesel/HOME as injected fuel. The nozzle used for experimentation has three holes and a $0.25 \mathrm{~mm}$ diameter. In the present work, advanced injection timing of $27^{\circ} \mathrm{bTDC}$ and $240 \mathrm{bar}$ IOP was used to investigate the effect of diesel/HOME and producer gas on the diesel engine. The different shapes of the combustion chamber such as HCC, LSCC, DSCC and TRCC were used for the dual-fuel engine operation and performance, emission characteristics were obtained.

All experiments were carried out at a constant loading from 0 to $80 \%$ with varying amounts of inducted fuel supply. The producer gas was measured by a venturi-meter with a digital flowmeter and flow is controlled by a control valve. Load, speed, airflow, EGT, cylinder pressure, $\mathrm{HC}, \mathrm{CO}, \mathrm{NO}_{\mathrm{X}}$, and smoke were recorded for each test. At least five sets of observations were collected to ensure the accuracy of the measured data. In addition, the experimental arrangements were prepared to be compatible with repeatable measurements.

In the transesterification process, the oil was combined with methanol by a $6: 1$ ratio, the 98 percent of sulfuric acid concentration by an additional 1 percent $v / v$ honge oil was added to the catalyst and heated on a hotplate by $60^{\circ} \mathrm{C}$ in a water-chilled mixing chamber. The esterification reaction is therefore improved. The period to react to the fusion was $60 \mathrm{~min}$. The resulting blend results in the synthesis of methyl ester [50-54]. Figure 2 illustrates the preparation of biodiesel and Table 4 shows the fatty acid content of honge biodiesel [50]. Figure 1 illustrates the (a) Gasifier (b) gasifier-engine setup.

\subsection{Analysis of Uncertainty}

The error analysis of experimental data is calculated by using systematic calculations. The overall uncertainty is calculated using the below equation:

$$
\frac{U y}{y}=\sqrt{\sum_{i=1}^{n}\left(\frac{1}{y} \frac{\partial y}{\partial x i}\right)^{2}}
$$

where,

$y$-specific factor which depends on the parameter $x i$;

Uy-level of uncertainties or variation in $y$;

Overall uncertainty $=$

$$
\begin{aligned}
& \text { Uncertainty (\%) of }\left(\mathrm{EGT}^{2}\right)+\mathrm{CO}^{2} \text { emission }^{2}+
\end{aligned}
$$

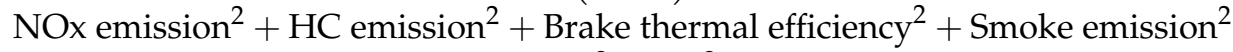

$$
\begin{aligned}
& \sqrt{+\mathrm{ID}^{2}+\mathrm{CD}^{2}} \\
& =\sqrt{\text { Uncertainty }(\%) \text { of }(0.55+0.4+0.45+0.40+0.35+0.5+0.8+0.5} \\
& = \pm 1.95
\end{aligned}
$$




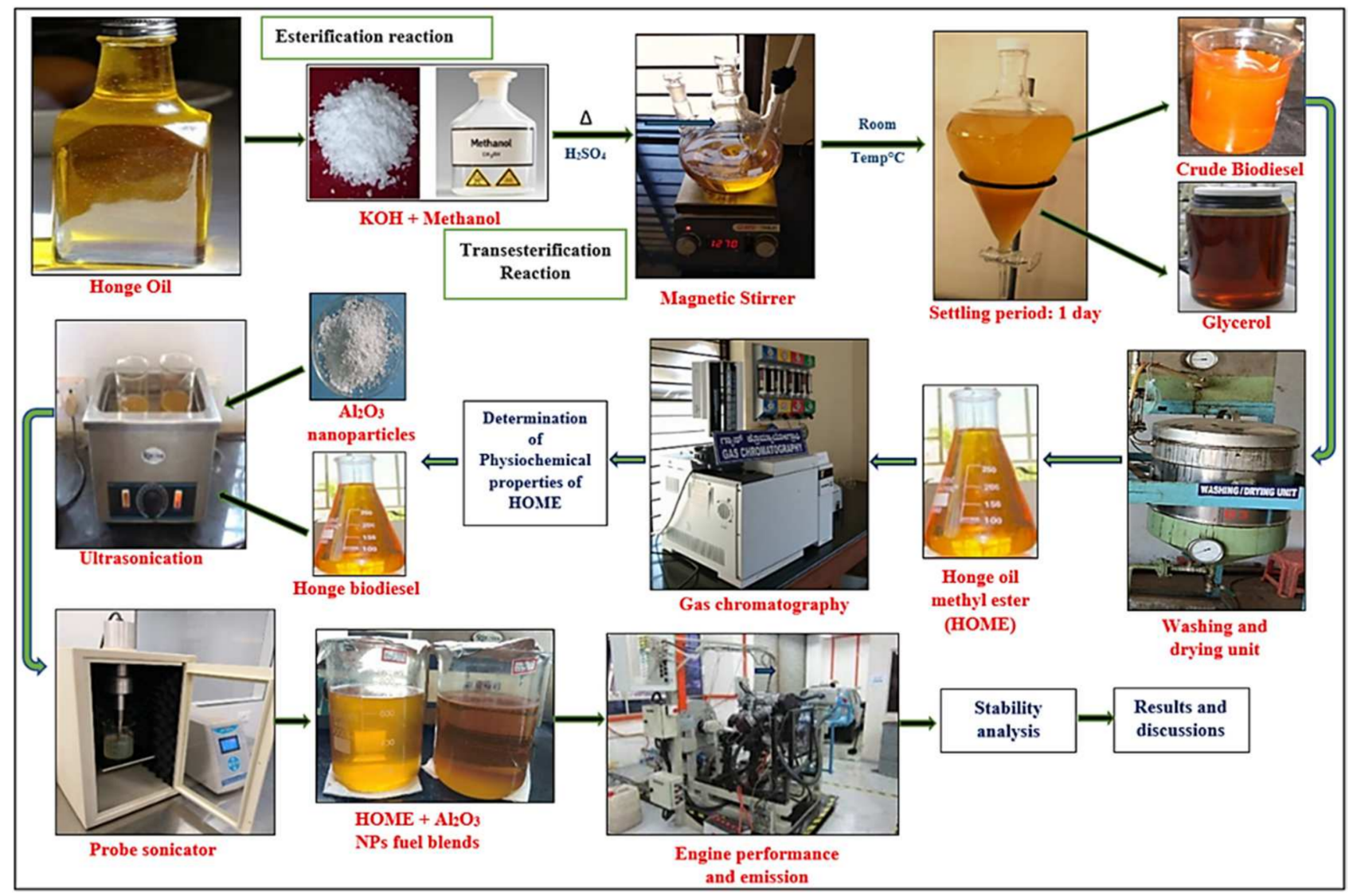

Figure 2. Preparation of honge biodiesel (adapted from Elsevier [50] with permission, License Number 5140860661341).

Table 4. The fatty acid profile of honge oil methyl ester (adapted from Elsevier [50] with permission, License Number 5140860661341).

\begin{tabular}{cc}
\hline Carbon Content (C) & $\begin{array}{c}\text { Honge Oilwt. } \\
\text { (\%) }\end{array}$ \\
\hline $16: 0$ & 11.65 \\
$18: 0$ & 7.50 \\
$18: 1$ & 43.79 \\
$18: 2$ & 14.64 \\
$20: 0$ & 1.35 \\
$20: 1$ & 9.88 \\
$22: 0$ & 4.45 \\
$24: 0$ & 2.21 \\
\hline
\end{tabular}

\section{Results and Discussion}

The present work describes the effect of the shapes of the combustion chamber, illustrated in Figure $3 \mathrm{a}-\mathrm{c}$, on the emissions and performance of the internal combustion engine in dual-fuel mode using diesel/HOME-PG combinations at various loads. The injection opening pressures of 205 and 240 bar were used for diesel-PG and HOME-PG, respectively. The injection nozzle of six holes and $0.25 \mathrm{~mm}$ size for HOME-PG and four holes and $0.25 \mathrm{~mm}$ size for diesel-PG was adopted.

In this section, the results of the dual-fuel engine operation using diesel/HOME as injected fuel and PG as inducted fuel with different combustion chamber shapes such as HCC, LSCC, DSCC, and TRCC were presented. 


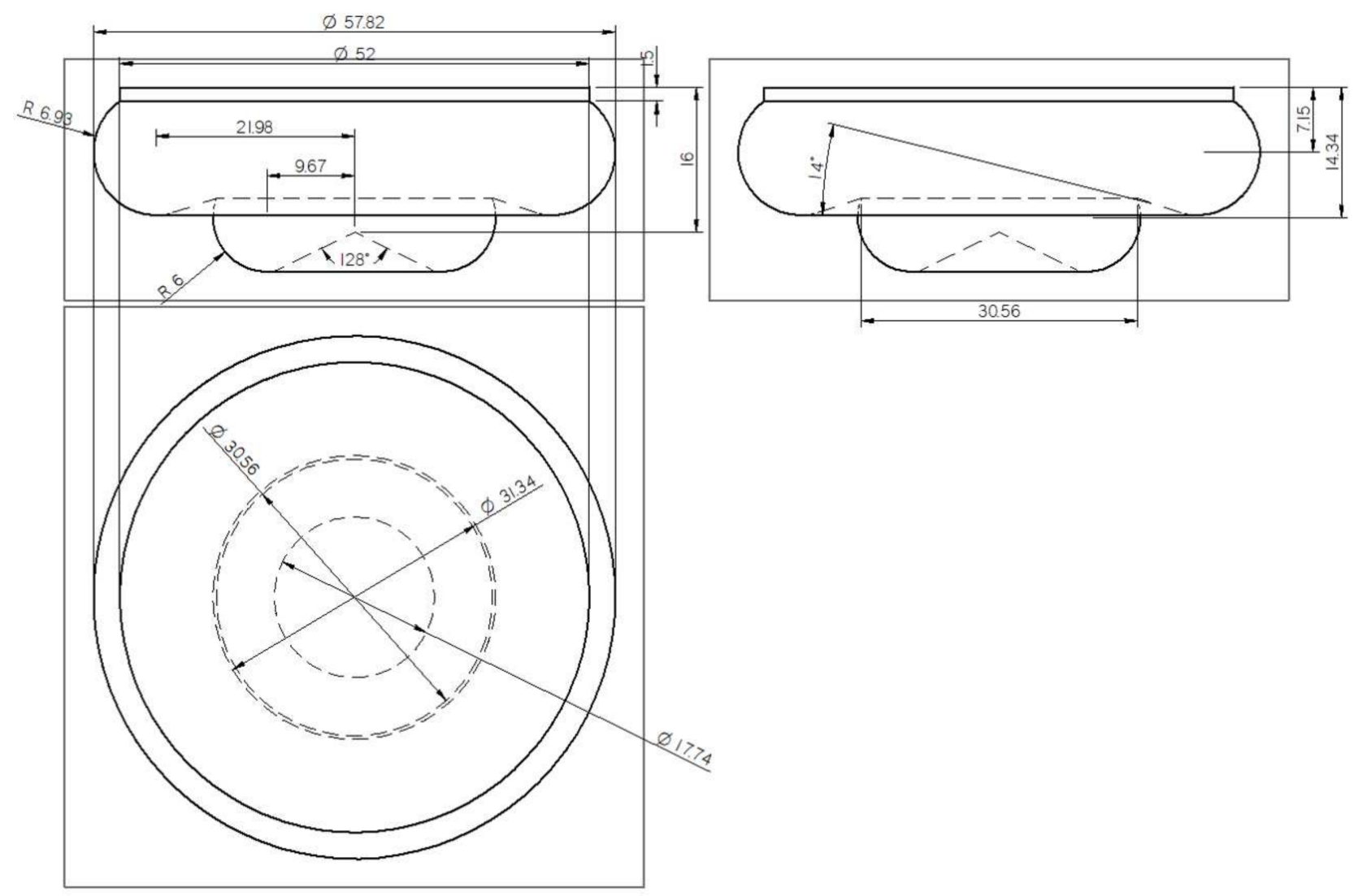

(a) Lateral Swirl Combustion Chamber
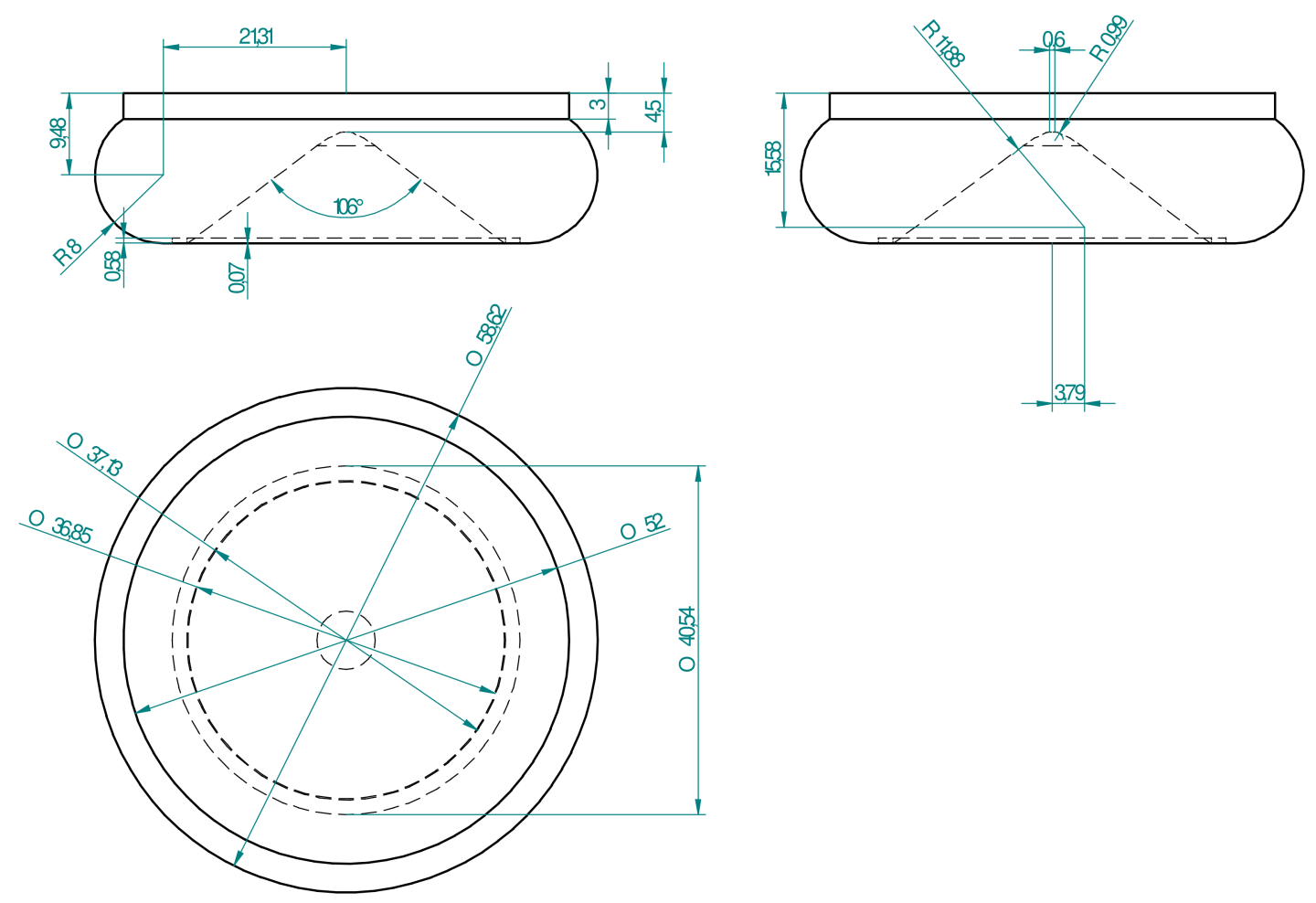

(b) Dual Swirl Combustion Chamber

Figure 3. Cont. 

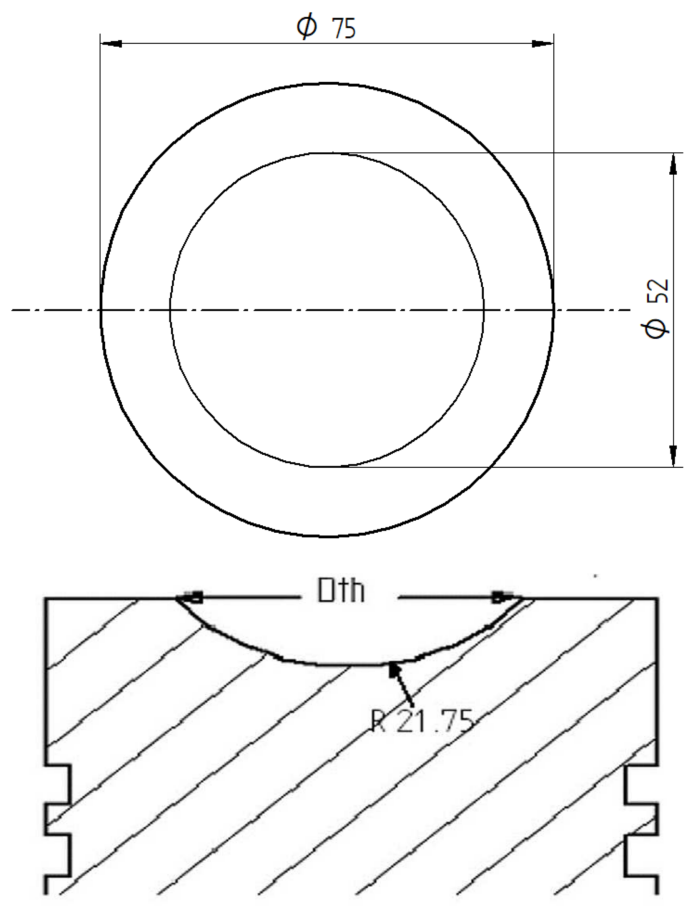

(c) Hemispherical Combustion Chamber

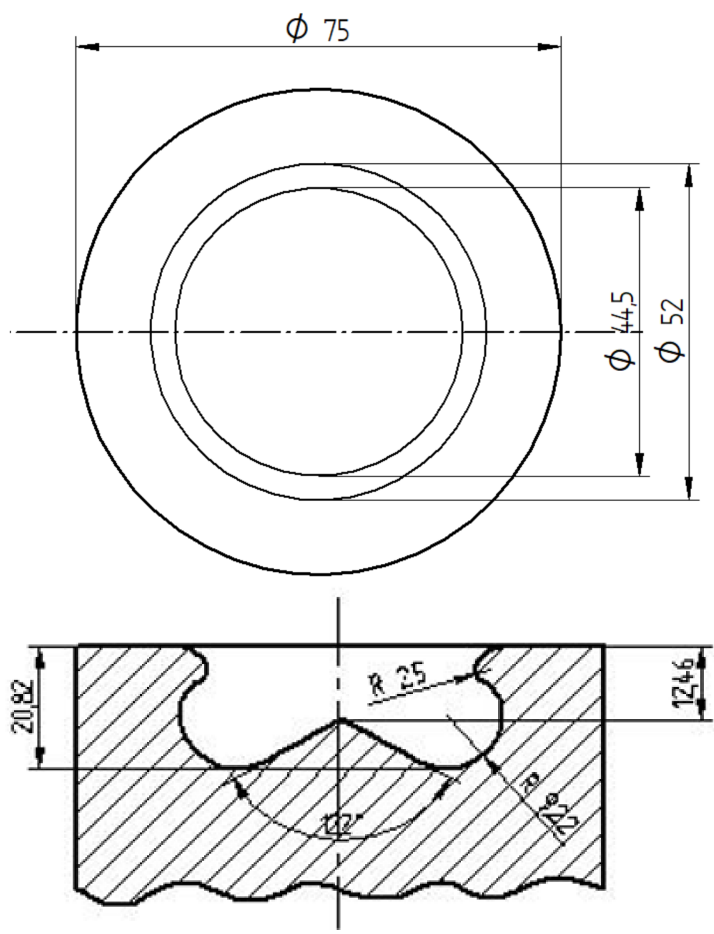

(d) Toroidal Reentrant Combustion Chamber

Figure 3. Combustion chamber types (shapes).

\subsection{Performance Parameters}

The variation of BTE with BP using different forms of combustion chambers is shown in Figure 4. The BTE for the dual-fuel diesel-PG operation was superior to the HOME-PG operation for the whole load range. This is because of the lower HV of the HOME and PG. Experimental results show that the HOME-PG combination with TRCC offers improved performance than all other forms of combustion chambers tested. This is because the TRCC prevents the propagating flame in the squish area, thus ensuring an improved HOME and PG-air mixture and increased airflow by increasing the vortex. From the results, it was observed that the TRCC was able to direct the flow properly into the combustion chamber, despite the load. The BTE for the HOME-PG combination with HCC, LSCC, DSCC, and TRCC was $17 \%, 17.2 \%, 17.8 \%$, and $18 \%$, compared with the $19.1 \%$ for the PG-diesel combination with HCC.

The variation of the EGT with BP using different forms of combustion chambers is shown in Figure 5. For the dual-fuel diesel-PG operation, the EGT was lower than the operation with HOME-PG for a given load range. This is due to the diesel and PG-air improved mixing, which will lead to almost complete combustion of the fuel. Most of the heat released during combustion is used for work, hence lowers EGT. Due to the higher viscosity of HOME, it will not mix properly with PG, and air causes combustion to take place in later stages resulting in higher EGT. The EGT for the HOME-PG combination with HCC, LSCC, DSCC, and TRCC was $402,391,382$, and $360^{\circ} \mathrm{C}$, compared to $330{ }^{\circ} \mathrm{C}$ for the PG-diesel combination with HCC.

\subsection{Emission Characteristics}

Figure 6 shows the variation of smoke opacity with BP for different forms of combustion chambers. The incomplete combustion occurs due to poor air supply and improper air-fuel mixing. Water is still produced, but carbon monoxide and carbon are produced instead of carbon dioxide leading to production of carbon as soot. The operation with diesel-PG has lesser smoke opacity than the operation with HOME-PG for the given load range. This is as a result of the viscosity and free fatty acid in HOME, which causes a lower 
fuel-air mixture [48]. However, the experimental results show lower levels of smoke with TRCC than all other combustion chamber types tested. This is on account of the improved mixing of air-fuel and turbulence within the combustion chamber, leading to absolute combustion. Soot plays an unwanted part in the energy generation from combustion processes, whereas soot decreases total combustion process efficiency. Soot formation is linked to the HC chains creating carbon solid clusters. These reactions happen in the gaseous phase and compete with the energy discharge during the oxidation process of the HC [55]. The use of the modified CC, biodiesel-producer gas combination reduces the soot formation considerably [56-60]. For the operation with HOME-PG, the smoke levels with HCC, LSCC, DSCC, and TRCC were 56.6, 46.5, 45, and $31.3 \mathrm{HSU}$ compared to $27.5 \mathrm{HSU}$ for operation with diesel-PG and HCC.

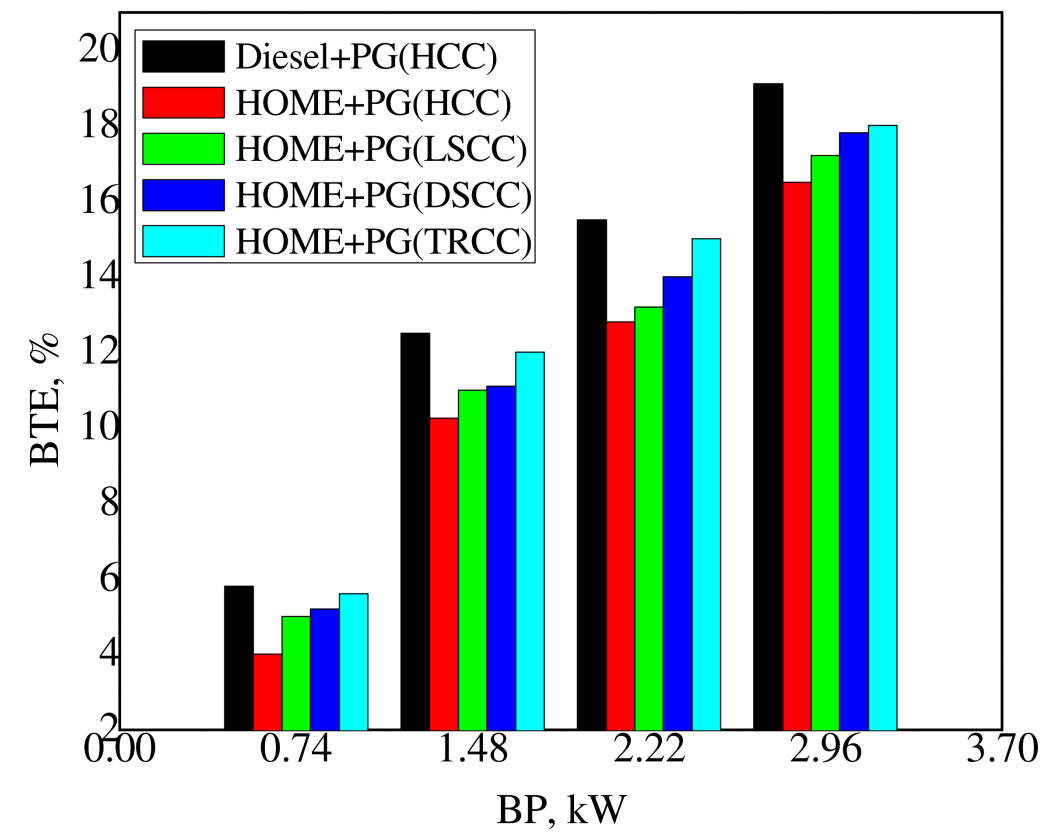

Figure 4. Effect of the combustion chamber type on BTE.

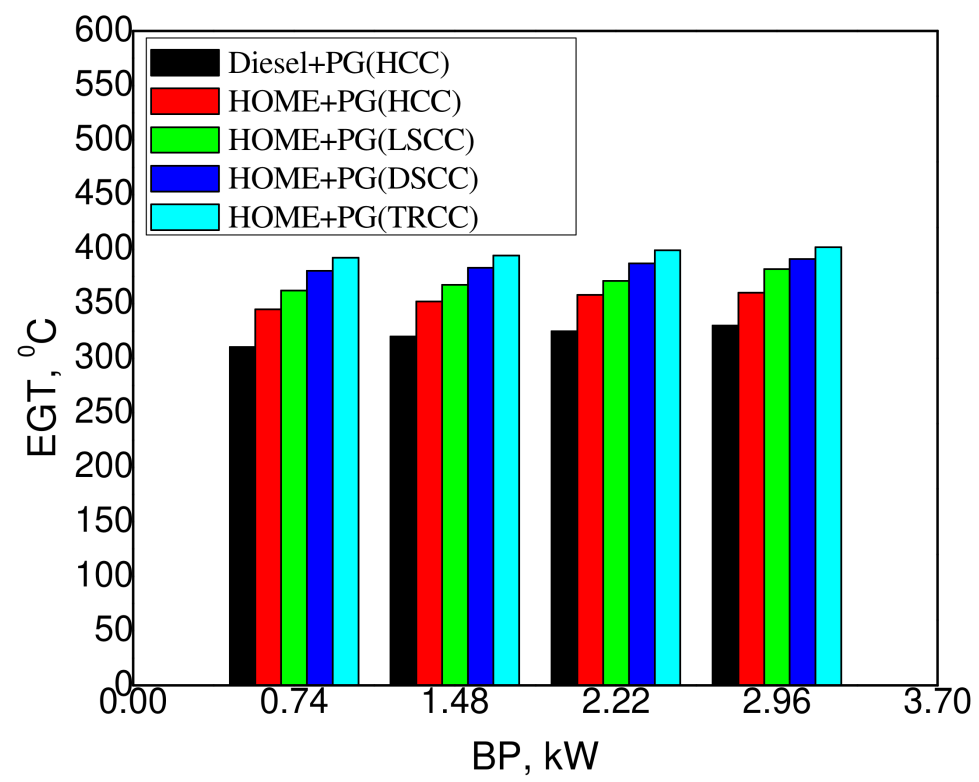

Figure 5. Effect of the combustion chamber type on EGT. 


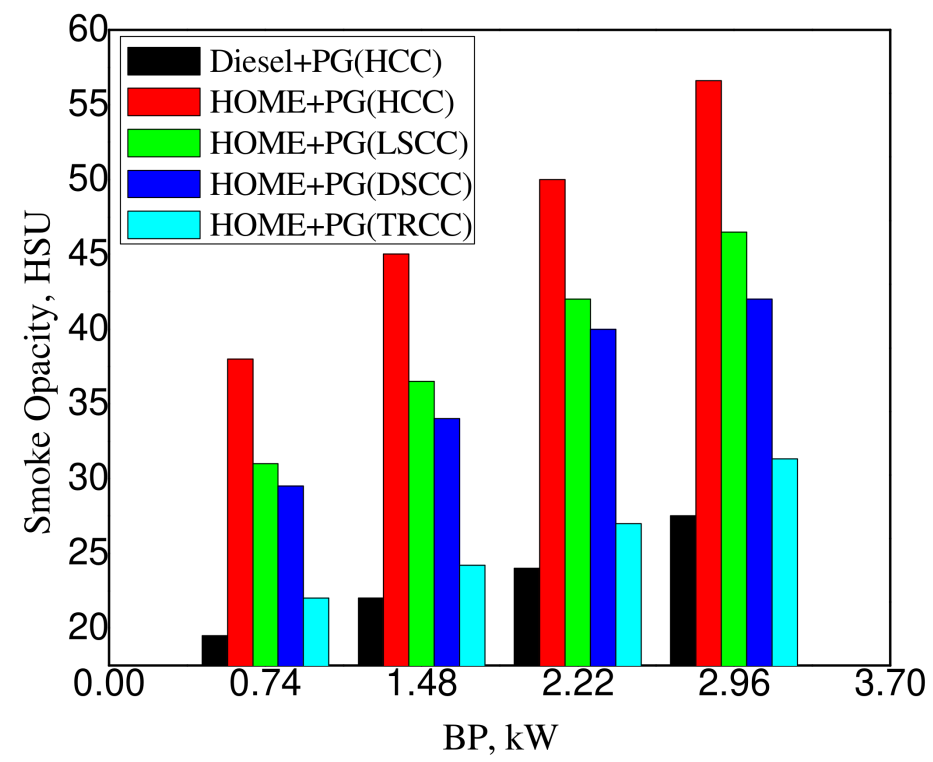

Figure 6. Effect of the combustion chamber type on smoke.

Figures 7 and 8 illustrate variations of UBHC and $\mathrm{CO}$ emissions for operation with diesel/HOME-PG for different combustion chambers. For HOME-PG operation, the UBHC and CO emissions were higher than the operation with diesel-PG for load range. This is because of the partial combustion of the HOME-PG combination due to insufficient oxygen for combustion, a lower HV of HOME and PG, and higher viscosity of HOME. However, the lower UBHC and CO emission levels resulted in TRCC compared to all other combustion chambers for the HOME-PG operation. This may be due to higher turbulence and higher temperature with TRCC, less heat loss, and improved oxidation, reducing $\mathrm{CO}$ and UBHC emissions. For operation using HOME-PG, the levels of UBHC with HCC, LSCC, DSCC, and TRCC were 46, 45, 36.3, and 35 ppm, compared to 33 ppm for the diesel-PG combination with HCC. Likewise, CO levels for the PG-HOME combination with HCC, LSCC, DSCC, and TRCC were $0.345 \%, 0.34 \%, 0.32 \%$, and $0.31 \%$ compared to $0.26 \%$ for the PG-diesel combination with HCC.

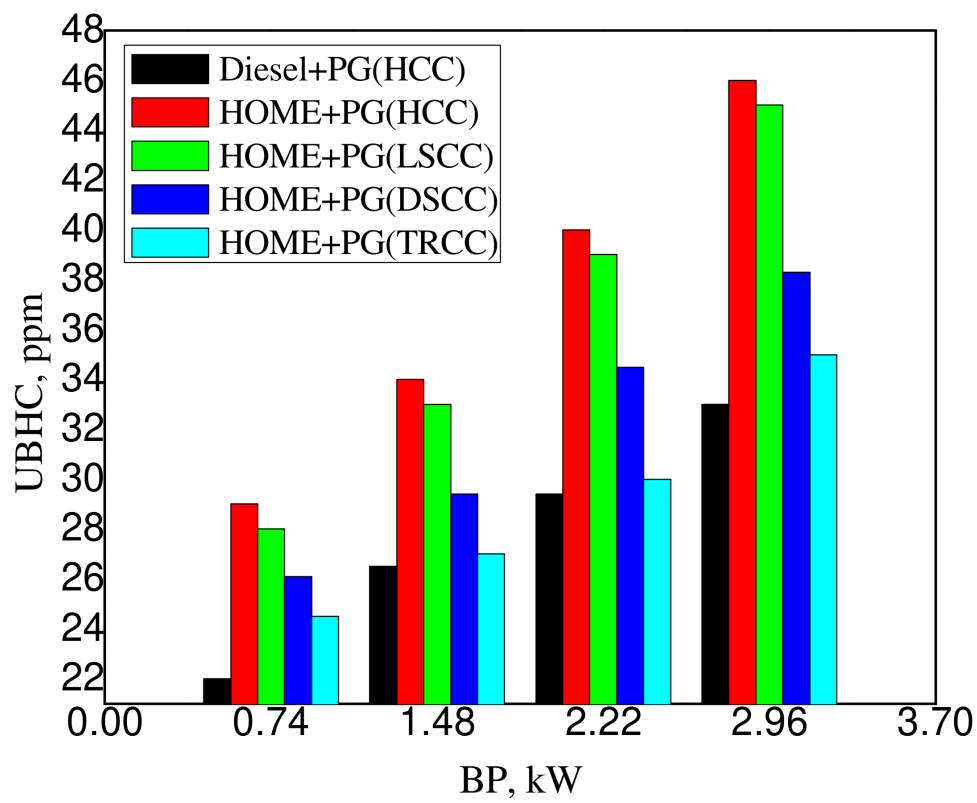

Figure 7. Effect of the combustion chamber on UBHC. 


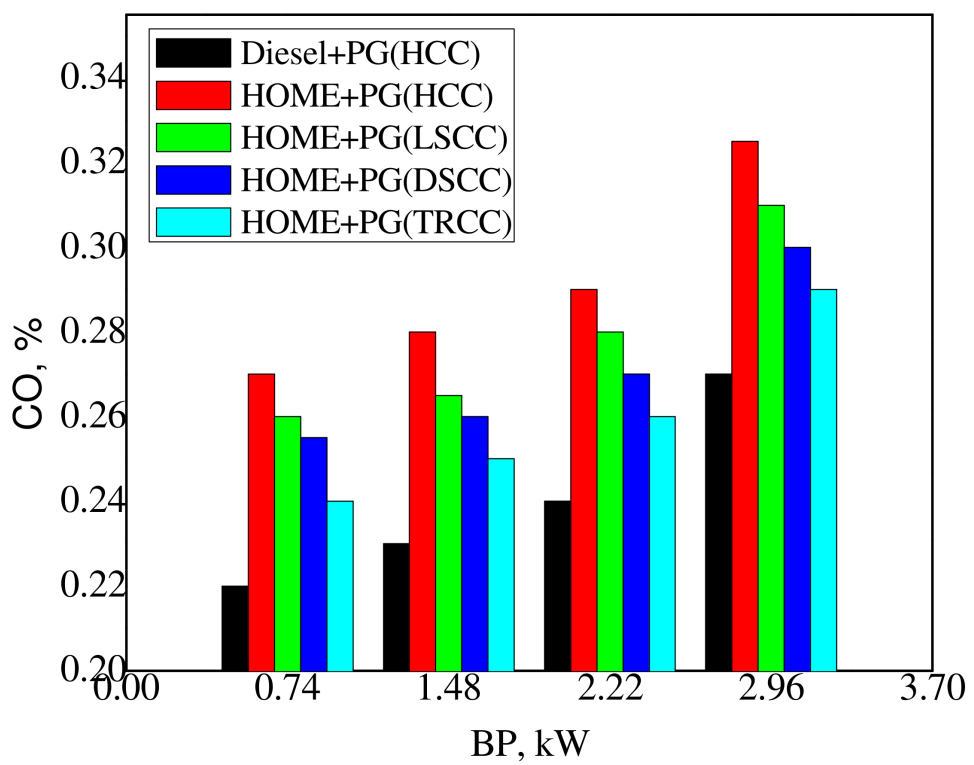

Figure 8. Effect of the combustion chamber type on CO.

Figure 9 shows the $\mathrm{NO}_{X}$ variation with $\mathrm{BP}$ using different forms of combustion chambers. For operation with the HOME-PG, $\mathrm{NO}_{\mathrm{X}}$ levels were lower than the diesel-PG combination with HCC for the entire load range. There is a higher heat release rate in the diesel-PG mode in the premixed combustion phase than in the HOME-PG mode. HOMEPG operation with TRCC results in a slightly higher $\mathrm{NO}_{X}$ emission due to improved combustion of the homogeneous mixture formed and greater heat release before TDC than all other combustion chamber forms tested. The presence of oxygen in the HOME leads to improved combustion and higher peak temperature, and $\mathrm{NO}_{\mathrm{X}}$. The $\mathrm{NO}_{\mathrm{X}}$ emissions for a combination of PG-HOME with HCC, LSCC, DSCC, and TRCC were 100, 105, 106, and $110 \mathrm{ppm}$, compared to $115 \mathrm{ppm}$ for operation with diesel-PG and HCC.

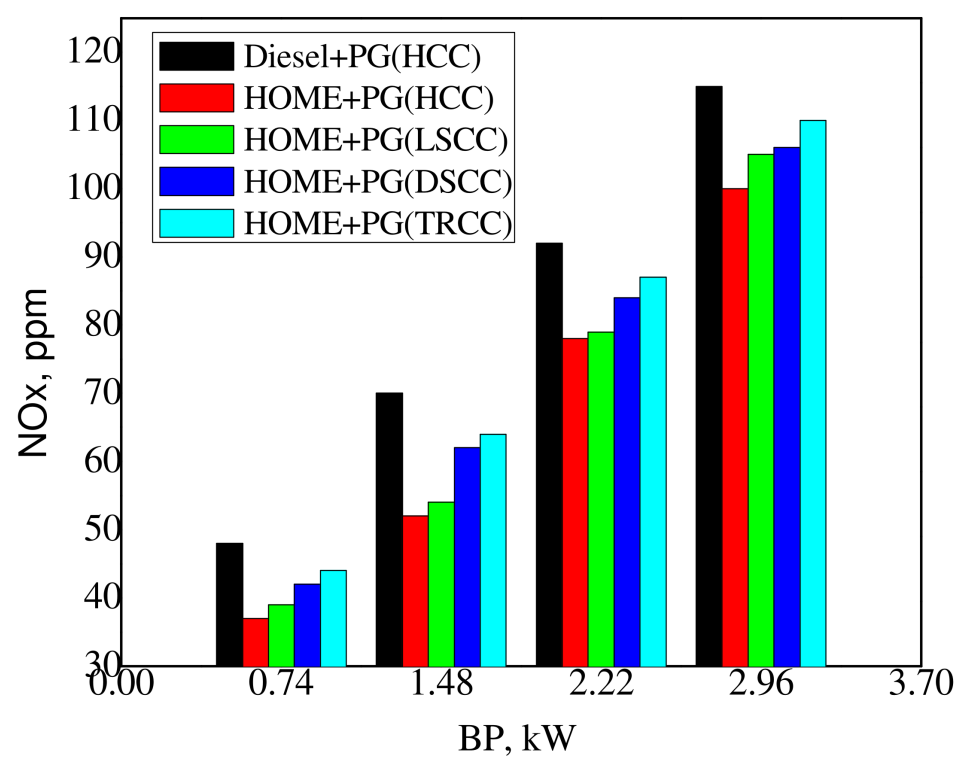

Figure 9. Effect of the combustion chamber type on $\mathrm{NO}_{\mathrm{X}}$.

\subsection{Combustion Parameters}

The ignition delay (ID) variation with the BP for the use of different forms of combustion chambers is shown in Figure 10. The operation of HOME-PG results in a decrease of ID with an increase in BP for all forms of combustion chambers tested. 


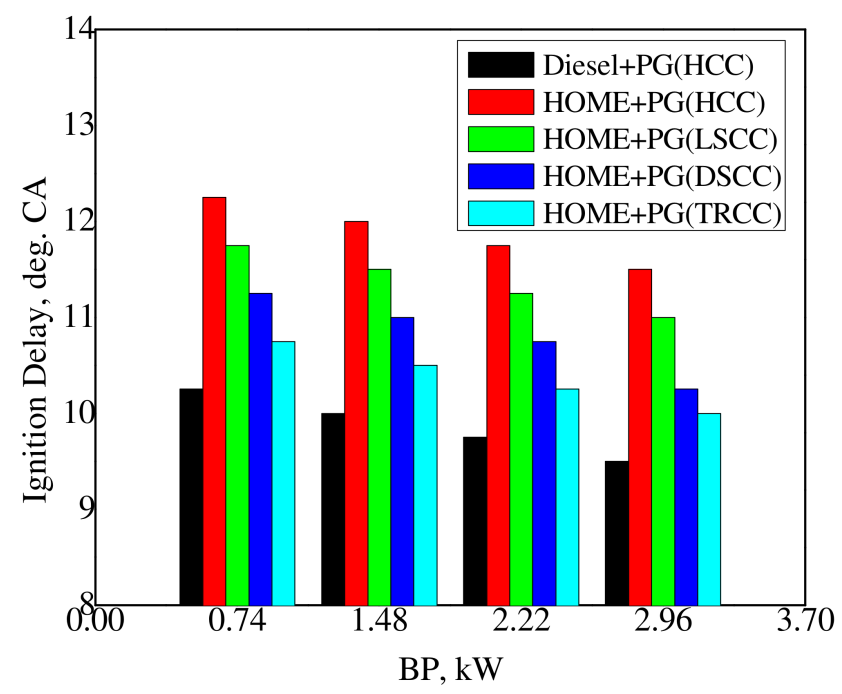

Figure 10. Effect of combustion chamber type on ignition delay.

The results show that the increase in BP with the rise in the quantity of fuel burnt inside the combustion chamber and the subsequent increase in temperature leads to a reduction in the ID for all the combustion chamber shapes. However, the ID was lower for the combination of diesel-PG than the HOME-PG with HCC. This may be due to the lower HV of PG and HOME, and the lower PG flame temperature, and the higher viscosity of HOME. However, for the HOME-PG operation, a lower ID was observed with TRCC than the HCC, LSCC, and DSCC. This might be certified to a superior air-fuel mixture and a higher temperature of combustion. The ID for the HOME-PG combination with HCC, LSCC, DSCC, and TRCC was 12.25, 11.75, 11.25, and 10.75 degrees CA, as compared to 10.25 degrees CA for the diesel-PG combination with HCC.

The variation in combustion duration as a function of BP is shown in Figure 10. Combustion duration increases with $\mathrm{BP}$ with all forms of combustion chambers due to the increased amount of fuel supply. The results showed a longer burning time with the HOME-PG combination than with the diesel-PG combination for the same form of the combustion chamber. This is because of the higher HOME viscosity, which causes inappropriate air-fuel mixing and requires additional time for preparation. Figure 11 illustrates the effect of the combustion chamber type on combustion duration.

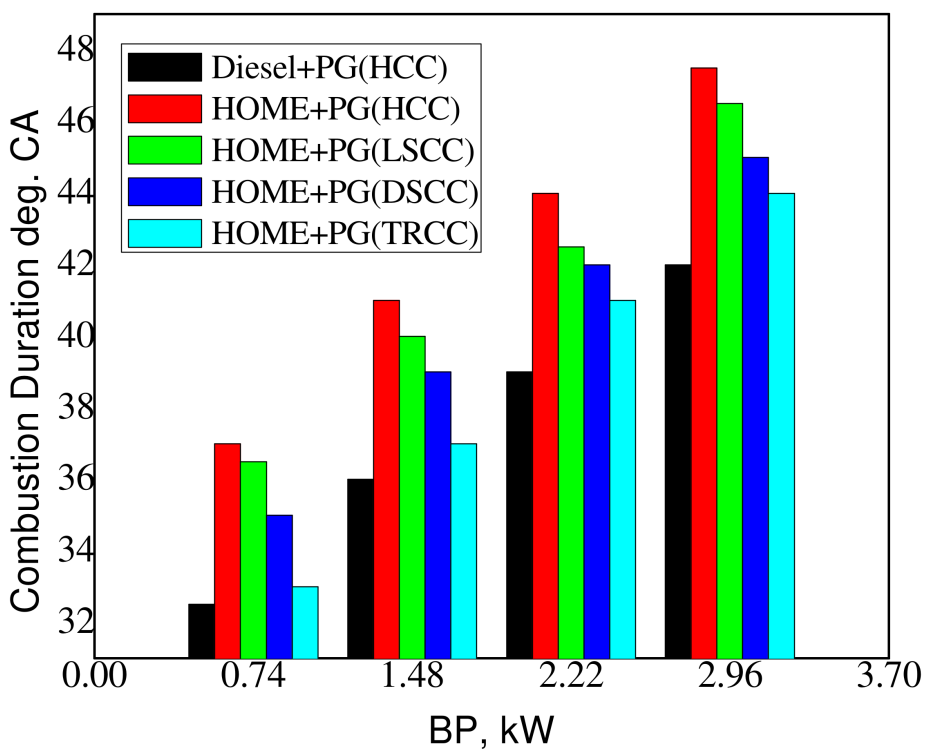

Figure 11. Effect of the combustion chamber type on combustion duration. 
However, the combustion duration observed for the HOME-PG combination with TRCC is lower than all other combustion chamber shapes tested. This might be certified to perfection in mixing injected fuel with an air-PG mixture due to an improved squish. The combustion duration of the HOME-PG combination with HCC, LSCC, DSCC, and TRCC was found to be $47.5,46.5,45$, and 44 degrees CA compared to 42 degrees CA diesel-PG combination with HCC.

The variation of fuel substitution for dual-fuel diesel/HOME-PG operation at different $\mathrm{BP}$ is shown in Figure 12. The higher fuel substitution resulted in diesel-PG operation compared with the HOME-PG as conditions were the same. Cetane number, viscosity, and $\mathrm{HV}$ of fuel are accountable for this tendency. Experimental results show that, for the HOME-PG operation, fuel substitution for the TRCC is higher than all other forms of combustion chambers. The TRCC mixes air-fuel properly due to the higher vortex and squish in the chamber, allowing improved combustion of the diesel/HOME with the PG. Fuel replacement was higher at lower loads due to proper control of injected fuel supply, but less with higher loads. As a result, the injected fuel supply slightly increased at higher loads, which leads to improved combustion of the PG. The fuel substitution for the HOME-PG combination with TRCC, DSCC, LSCC, and HCC proved to be $67 \%, 65.5 \%$, $64 \%$, and $59 \%$ compared to $71 \%$ for the operation with diesel-PG and HCC.

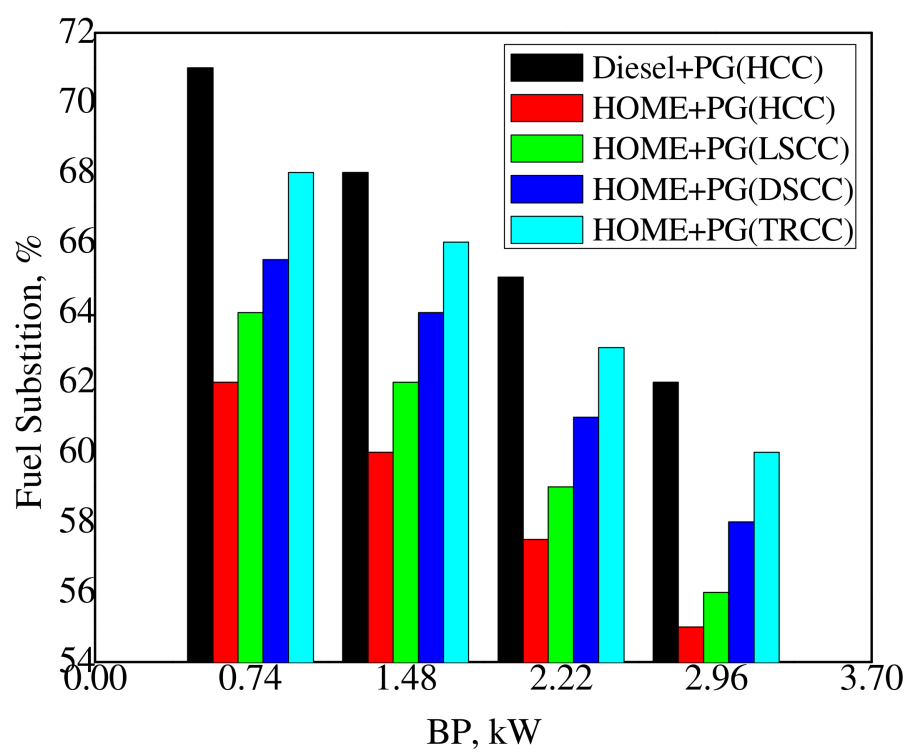

Figure 12. Effect of the combustion chamber type on fuel substitution.

Similar results for BTE, EGT, $\mathrm{HC}, \mathrm{CO}$ and $\mathrm{NO}_{\mathrm{X}}$ were found by $0 \mathrm{D}$ thermodynamic analysis for different fuel combinations [61-65]. The literature for 0D thermodynamic analysis of CI engines operating in dual-fuel mode using producer gas and liquid fuel combinations were not analyzed in the preceding literature. There is further scope for the study of the OD analysis for the dual-fuel engine operation.

\section{Conclusions}

The function of a dual-fuel engine with diesel/HOME-PG from redgram stalk showed that the performance is considerably affected by the type of the combustion chamber and liquid fuel type. However, comparing the shape of the combustion chamber to enhance performance and reduce emissions was successful. The engine was operated with the HOME-PG combination, and the TRCC combustion chamber results in a $9 \%$ increase in BTE, 10.4\% reduction in EGT compared to HOME-PG with HCC. The operation with HOME-PG and TRCC resulted in a $44 \%$ reduction in smoke, $23.9 \%$ of UBHC, $10.14 \%$ $\mathrm{CO}$ but a $9 \%$ increase in $\mathrm{NO}_{X}$ levels compared to HOME-PG with HCC. A 17\% lower ignition delay and $11.5 \%$ shorter combustion duration were observed for operation with 
diesel-PG than the operation with HOME-PG and HCC. Operating conditions being the same diesel-PG operation has 71\% fuel substitution with HCC, and the HOME-PG operation has $68 \%$ with TRCC which is $100 \%$ biofuel operation. Overall, it was concluded that the diesel/HOME-PG combination is an alternative and sustainable fuel combination for $\mathrm{CI}$ engine operation. Additionally, the diesel-PG combination does not need any significant engine modifications and has satisfactory performance with lower emissions but the HOME-PG combination requires some modifications.

In future research, to describe $\mathrm{BTE}, \mathrm{HC}, \mathrm{CO}$ and $\mathrm{NO}_{x}$ parameters, $0 \mathrm{D}$ thermodynamic analysis based on measured in-cylinder pressure can be performed. It is crucial to get insight into the combustion process through heat release rate and in-cylinder temperature to be able to present underlying processes.

Author Contributions: Conceptualization, K.M.A., N.R.B. and M.E.M.S.; methodology, K.M.A., N.R.B., S.G. and M.E.M.S.; validation, M.E.M.S., T.M.Y.K. and M.A.A.B.; formal analysis, M.A.M. and N.H.; investigation, M.E.M.S.; resources, N.R.B., V.S.Y. and K.M.A.; writing-original draft preparation, K.M.A., N.R.B., S.G. and M.E.M.S.; writing-review and editing, T.M.Y.K., K.S. and M.A.M.; visualization, S.A.G. and K.M.A.; support, review and editing, A.E. and M.A.; supervision, N.R.B. and V.S.Y.; funding acquisition, T.M.Y.K., A.E. and M.A. All authors have read and agreed to the published version of the manuscript.

Funding: Deanship of Scientific Research at King Khalid University, Grant Number R.G.P.1/251/42 and Taif University Researchers Supporting Project Number (TURSP-2020/205), Taif University, Taif, Saudi Arabia.

Institutional Review Board Statement: Not applicable.

Informed Consent Statement: Not applicable.

Data Availability Statement: Not applicable.

Acknowledgments: The authors extend their appreciation to the Deanship of Scientific Research at King Khalid University for funding this work through Grant Number R.G.P.1/251/42. This work was supported by Taif University Researchers Supporting Project Number (TURSP-2020/205), Taif University, Taif, Saudi Arabia.

Conflicts of Interest: The authors declare no conflict of interest.

\section{Nomenclature}

BTE Brake thermal efficiency

$\mathrm{CO}$ Carbon monoxide

$\mathrm{CO}_{2} \quad$ Carbon dioxide

$\mathrm{CH}_{4} \quad$ Methane

CA Crank angle

HOME Honge oil methyl ester

HV Heating value

DI Direct injection

DSCC Dual swirl combustion chamber

GHG Greenhouse gas

HCC Hemispherical combustion chamber

HSU Hartridge smoke unit

IOP Injection opening pressure

ID Ignition delay

LSCC Low swirl combustion chamber

PG Producer gas

RGS Redgram stalk

TDC Top dead center

TRCC Toroidal Rre-entrant combustion chamber

VCR Variable compression ratio

UBHC Unburnt hydrocarbon 


\section{References}

1. Yaliwal, V.; Banapurmath, N.; Gireesh, N.; Tewari, P. Production and utilization of renewable and sustainable gaseous fuel for power generation applications: A review of literature. Renew. Sustain. Energy Rev. 2014, 34, 608-627. [CrossRef]

2. Sateesh, K.A.; Yaliwal, V.S.; Soudagar, M.E.M.; Banapurmath, N.R.; Fayaz, H.; Safaei, M.R.; Elfasakhany, A.; El-Seesy, A.I. Utilization of biodiesel/Al2O3 nanoparticles for combustion behavior enhancement of a diesel engine operated on dual fuel mode. J. Therm. Anal. Calorim. 2021. Available online: https:/ /ink.springer.com/article/10.1007/s10973-021-10928-7 (accessed on 10 August 2021).

3. Soudagar, M.E.M.; Khan, H.M.; Khan, T.; Razzaq, L.; Asif, T.; Mujtaba, M.; Hussain, A.; Farooq, M.; Ahmed, W.; Shahapurkar, K. Experimental Analysis of Engine Performance and Exhaust Pollutant on a Single-Cylinder Diesel Engine Operated Using Moringa Oleifera Biodiesel. Appl. Sci. 2021, 11, 7071. [CrossRef]

4. Funke, A.; Niebel, A.; Richter, D.; Abbas, M.M.; Müller, A.K.; Radloff, S.; Paneru, M.; Maier, J.; Dahmen, N.; Sauer, J. Fast pyrolysis char-Assessment of alternative uses within the bioliq®concept. Bioresour. Technol. 2016, 200, 905-913. [CrossRef]

5. Annual Report 2016-17. Central Electricity, Authority (CEA): India, New Delhi. Available online: https://irade.org/Inside_ Annual\%20Report-2016-17_04-11-2017_LR.pdf (accessed on 26 January 2020).

6. The Energy and Resources Institute. Study on the Sustainability of Biomass Based Power Generation in Karnataka Bangalore. TERI, 2013; p. 46. Available online: https:/ / www.researchgate.net/publication/283335779_Study_on_the_sustainability_of_ Biomass_based_power_generation_in_Karnataka (accessed on 15 September 2021).

7. Harari, P.; Banapurmath, N.; Yaliwal, V.; Soudagar, M.E.M.; Khan, T.Y.; Mujtaba, M.; Safaei, M.R.; Akram, N.; Goodarzi, M.; Elfasakhany, A. Experimental investigation on compression ignition engine powered with pentanol and thevetia peruviana methyl ester under reactivity controlled compression ignition mode of operation. Case Stud. Therm. Eng. 2021, 25, 100921. [CrossRef]

8. Keerthi Kumar, N.; Banapurmath, N.; Chandrashekar, T.; Jatadhara, G.; Soudagar, M.E.M.; Anqi, A.E.; Mujtaba, M.; Goodarzi, M.; Elfasakhany, A.; Siddiqui, M.I.H. Effect of Parameters Behavior of Simarouba Methyl Ester Operated Diesel Engine. Energies 2021, $14,4973$.

9. Soudagar, M.E.M.; Mujtaba, M.; Safaei, M.R.; Afzal, A.; Ahmed, W.; Banapurmath, N.; Hossain, N.; Bashir, S.; Badruddin, I.A.; Goodarzi, M. Effect of Sr@ ZnO nanoparticles and Ricinus communis biodiesel-diesel fuel blends on modified CRDI diesel engine characteristics. Energy 2021, 215, 119094. [CrossRef]

10. Bala Prasad, K.; Dhana Raju, V.; Ahamad Shaik, A.; Gopidesi, R.K.; Sreekara Reddy, M.B.S.; Soudagar, M.E.M.; Mujtaba, M.A. Impact of injection timings and exhaust gas recirculation rates on the characteristics of diesel engine operated with neat tamarind biodiesel. Energy Sources Part A Recovery Util. Environ. Eff. 2021, 1-19. [CrossRef]

11. Bala Prasad, K.; Meduri, O.; Dhana Raju, V.; Azmeera, A.K.; Venu, H.; Subramani, L.; Soudagar, M.E.M. Effect of split fuel injection strategies on the diverse characteristics of CRDI diesel engine operated with tamarind biodiesel. Energy Sources Part $A$ Recovery Util. Environ. Eff. 2020, 1-19. [CrossRef]

12. Fayaz, H.; Mujtaba, M.; Soudagar, M.E.M.; Razzaq, L.; Nawaz, S.; Nawaz, M.A.; Farooq, M.; Afzal, A.; Ahmed, W.; Khan, T.Y. Collective effect of ternary nano fuel blends on the diesel engine performance and emissions characteristics. Fuel 2021, 293, 120420. [CrossRef]

13. Mujtaba, M.A.; Muk Cho, H.; Masjuki, H.H.; Kalam, M.A.; Farooq, M.; Soudagar, M.E.M.; Gul, M.; Afzal, A.; Ahmed, W.; Raza, A.; et al. Effect of primary and secondary alcohols as oxygenated additives on the performance and emission characteristics of diesel engine. Energy Rep. 2021, 7, 1116-1124. [CrossRef]

14. Mujtaba, M.; Kalam, M.; Masjuki, H.; Gul, M.; Soudagar, M.E.M.; Ong, H.C.; Ahmed, W.; Atabani, A.; Razzaq, L.; Yusoff, M. Comparative study of nanoparticles and alcoholic fuel additives-biodiesel-diesel blend for performance and emission improvements. Fuel 2020, 279, 118434. [CrossRef]

15. Parikh, P.; Bhave, A.; Kapse, D. Study of thermal and emission performance of small gasifier-dual-fuel engine systems. Biomass 1989, 19, 75-97. [CrossRef]

16. Banapurmath, N.; Yaliwal, V.; Kambalimath, S.; Hunashyal, A.; Tewari, P. Effect of wood type and carburetor on the performance of producer gas-biodiesel operated dual fuel engines. Waste Biomass Valorization 2011, 2, 403-413. [CrossRef]

17. Barua, P.; Hossain, N.; Chowdhury, T.; Chowdhury, H. Commercial diesel application scenario and potential of alternative biodiesel from waste chicken skin in Bangladesh. Environ. Technol. Innov. 2020, 20, 101139. [CrossRef]

18. Lata, D.B.; Misra, A. Experimental investigations on the performance of a dual fuel diesel engine with hydrogen and LPG as secondary fuels. In Advances in Computer Science and Engineering; Springer: Berlin/Heidelberg, Germany, 2012; pp. 119-128.

19. Karabektas, M.; Ergen, G.; Hosoz, M. The effects of using diethylether as additive on the performance and emissions of a diesel engine fuelled with CNG. Fuel 2014, 115, 855-860. [CrossRef]

20. Yaliwal, V.; Banapurmath, N.; Hosmath, R.; Khandal, S.; Budzianowski, W.M. Utilization of hydrogen in low calorific value producer gas derived from municipal solid waste and biodiesel for diesel engine power generation application. Renew. Energy 2016, 99, 1253-1261. [CrossRef]

21. Liu, J.; Yang, F.; Wang, H.; Ouyang, M.; Hao, S. Effects of pilot fuel quantity on the emissions characteristics of a CNG/diesel dual fuel engine with optimized pilot injection timing. Appl. Energy 2013, 110, 201-206. [CrossRef]

22. Razzaq, L.; Imran, S.; Anwar, Z.; Farooq, M.; Abbas, M.M.; Mehmood Khan, H.; Asif, T.; Amjad, M.; Soudagar, M.E.M.; Shaukat, N.J.E. Maximising Yield and Engine Efficiency Using Optimised Waste Cooking Oil Biodiesel. Energies 2020, 13, 5941. [CrossRef] 
23. Banapurmath, N.; Tewari, P. Comparative performance studies of a 4-stroke CI engine operated on dual fuel mode with producer gas and Honge oil and its methyl ester (HOME) with and without carburetor. Renew. Energy 2009, 34, 1009-1015. [CrossRef]

24. Banapurmath, N.; Yaliwal, V.; Hosmath, R.; Indudhar, M.; Guluwadi, S.; Bidari, S. Dual fuel engines fueled with three gaseous and biodiesel fuel combinations. Biofuels 2018, 9, 75-87. [CrossRef]

25. Sombatwong, P.; Thaiyasuit, P.; Pianthong, K. Effect of pilot fuel quantity on the performance and emission of a dual producer gas-diesel engine. Energy Procedia 2013, 34, 218-227. [CrossRef]

26. Elnajjar, E.; Hamdan, M.O.; Selim, M.Y. Experimental investigation of dual engine performance using variable LPG composition fuel. Renew. Energy 2013, 56, 110-116. [CrossRef]

27. Hossain, N.; Hasan, M.H.; Mahlia, T.M.I.; Shamsuddin, A.H.; Silitonga, A.S. Feasibility of microalgae as feedstock for alternative fuel in Malaysia: A review. Energy Strategy Rev. 2020, 32, 100536. [CrossRef]

28. Sahoo, B.B.; Sahoo, N.; Saha, U.K. Effect of H2: CO ratio in syngas on the performance of a dual fuel diesel engine operation. Appl. Therm. Eng. 2012, 49, 139-146. [CrossRef]

29. Köse, H.; Ciniviz, M. An experimental investigation of effect on diesel engine performance and exhaust emissions of addition at dual fuel mode of hydrogen. Fuel Process. Technol. 2013, 114, 26-34. [CrossRef]

30. Lata, D.; Misra, A.; Medhekar, S. Effect of hydrogen and LPG addition on the efficiency and emissions of a dual fuel diesel engine. Int. J. Hydrogen Energy 2012, 37, 6084-6096. [CrossRef]

31. Lal, S.; Mohapatra, S. The effect of compression ratio on the performance and emission characteristics of a dual fuel diesel engine using biomass derived producer gas. Appl. Therm. Eng. 2017, 119, 63-72. [CrossRef]

32. Zhou, J.; Cheung, C.S.; Leung, C.W. Combustion, performance and emissions of a diesel engine with $\mathrm{H}_{2}, \mathrm{CH}_{4}$ and $\mathrm{H}_{2}-\mathrm{CH}_{4}$ addition. Int. J. Hydrogen Energy 2014, 39, 4611-4621. [CrossRef]

33. Roy, M.M.; Tomita, E.; Kawahara, N.; Harada, Y.; Sakane, A. Performance and emissions of a supercharged dual-fuel engine fueled by hydrogen-rich coke oven gas. Int. J. Hydrogen Energy 2009, 34, 9628-9638. [CrossRef]

34. Yoon, S.H.; Lee, C.S. Experimental investigation on the combustion and exhaust emission characteristics of biogas-biodiesel dual-fuel combustion in a CI engine. Fuel Process. Technol. 2011, 92, 992-1000. [CrossRef]

35. Ramadhas, A.; Jayaraj, S.; Muraleedharan, C. Dual fuel mode operation in diesel engines using renewable fuels: Rubber seed oil and coir-pith producer gas. Renew. Energy 2008, 33, 2077-2083. [CrossRef]

36. Wategave, S.; Banapurmath, N.; Sawant, M.; Soudagar, M.E.M.; Mujtaba, M.; Afzal, A.; Basha, J.S.; Alazwari, M.A.; Safaei, M.R.; Elfasakhany, A. Clean combustion and emissions strategy using reactivity controlled compression ignition (RCCI) mode engine powered with CNG-Karanja biodiesel. J. Taiwan Inst. Chem. Eng. 2021, 124, 116-131. [CrossRef]

37. El-Seesy, A.I.; Hassan, H.; Ibraheem, L.; He, Z.; Soudagar, M.E.M. Combustion, emission, and phase stability features of a diesel engine fueled by Jatropha/ethanol blends and n-butanol as co-solvent. Int. J. Green Energy 2020, 17, 793-804. [CrossRef]

38. Soudagar, M.E.M.; Afzal, A.; Safaei, M.R.; Manokar, A.M.; EL-Seesy, A.I.; Mujtaba, M.; Samuel, O.D.; Badruddin, I.A.; Ahmed, W.; Shahapurkar, K. Investigation on the effect of cottonseed oil blended with different percentages of octanol and suspended MWCNT nanoparticles on diesel engine characteristics. J. Therm. Anal. Calorim. 2020, 1-18. [CrossRef]

39. Mujtaba, M.; Masjuki, H.; Kalam, M.; Noor, F.; Farooq, M.; Ong, H.C.; Gul, M.; Soudagar, M.E.M.; Bashir, S.; Rizwanul Fattah, I. Effect of Additivized Biodiesel Blends on Diesel Engine Performance, Emission, Tribological Characteristics, and Lubricant Tribology. Energies 2020, 13, 3375. [CrossRef]

40. Usman, M.; Hussain, H.; Riaz, F.; Irshad, M.; Bashir, R.; Haris Shah, M.; Ahmad Zafar, A.; Bashir, U.; Kalam, M.A.; Mujtaba, M.A.; et al. Artificial Neural Network Led Optimization of Oxyhydrogen Hybridized Diesel Operated Engine. Sustainability 2021, 13, 9373. [CrossRef]

41. Malik, A.; Mohapatra, S. Biomass-based gasifiers for internal combustion (IC) engines-A review. Sadhana 2013, 38, 461-476. [CrossRef]

42. Das, D.; Dash, S.; Ghosal, M. Performance evaluation of a diesel engine by using producer gas from some under-utilized biomass on dual-fuel mode of diesel cum producer gas. J. Cent. South Univ. 2012, 19, 1583-1589. [CrossRef]

43. Nataraj, K.; Banapurmath, N.; Manavendra, G.; Yaliwal, V. Development of cooling and cleaning systems for enhanced gas quality for $3.7 \mathrm{~kW}$ gasifier-engine integrated system. Int. J. Eng. Sci. Technol. 2016, 8, 43-56. [CrossRef]

44. Asadullah, M. Barriers of commercial power generation using biomass gasification gas: A review. Renew. Sustain. Energy Rev. 2014, 29, 201-215. [CrossRef]

45. Shelke, G.N.; Mahanta, P. Feasibility study on utilization of biomass briquette in a conventional downdraft gasifier. Int. Energy J. 2016, 15, 157-166.

46. Yaliwal, V.; Banapurmath, N.; Tewari, P. Performance, combustion and emission characteristics of a single-cylinder, four-stroke, direct injection diesel engine operated on a dual-fuel mode using Honge oil methyl ester and producer gas derived from biomass feedstock of different origin. Int. J. Sustain. Eng. 2014, 7, 253-268. [CrossRef]

47. Akkoli, K.; Gangavati, P.; Banapurmath, N.; Yaliwal, V. Comparative study of various biofuel combinations derived from agricultural residues on the performance and emissions of CI engine. Int. J. Sustain. Eng. 2020, 13, 140-150. [CrossRef]

48. Akkoli, K.; Banapurmath, N.; Shivashimpi, M.; Soudagar, M.E.M.; Badruddin, I.A.; Alazwari, M.A.; Yaliwal, V.; Mujtaba, M.; Akram, N.; Goodarzi, M. Effect of injection parameters and producer gas derived from redgram stalk on the performance and emission characteristics of a diesel engine. Alex. Eng. J. 2021, 60, 3133-3142. [CrossRef] 
49. Akkoli, K.; Gangavati, P.; Banapurmath, N. Effect of Cooling Cleaning System on the Performance and Emission Characteristics of Producer Gas Operated Dual-Fuel CI Engine. Int. J. Appl. Eng. Res. 2019, 14, 687-693.

50. Soudagar, M.E.M.; Nik-Ghazali, N.-N.; Kalam, M.; Badruddin, I.A.; Banapurmath, N.; Ali, M.A.B.; Kamangar, S.; Cho, H.M.; Akram, N. An investigation on the influence of aluminium oxide nano-additive and honge oil methyl ester on engine performance, combustion and emission characteristics. Renew. Energy 2020, 146, 2291-2307. [CrossRef]

51. Afzal, A.; Soudagar, M.E.M.; Belhocine, A.; Kareemullah, M.; Hossain, N.; Alshahrani, S.; Saleel, C.; Subbiah, R.; Qureshi, F.; Mujtaba, M. Thermal Performance of Compression Ignition Engine Using High Content Biodiesels: A Comparative Study with Diesel Fuel. Sustainability 2021, 13, 7688. [CrossRef]

52. Aneeque, M.; Alshahrani, S.; Kareemullah, M.; Afzal, A.; Saleel, C.A.; Soudagar, M.E.M.; Hossain, N.; Subbiah, R.; Ahmed, M.H. The Combined Effect of Alcohols and Calophyllum inophyllum Biodiesel Using Response Surface Methodology Optimization. Sustainability 2021, 13, 7345. [CrossRef]

53. Teja, K.M.V.R.; Prasad, P.I.; Reddy, K.V.K.; Banapurmath, N.R.; Soudagar, M.E.M.; Khan, T.M.Y.; Badruddin, I.A. Influence of Combustion Chamber Shapes and Nozzle Geometry on Performance, Emission, and Combustion Characteristics of CRDI Engine Powered with Biodiesel Blends. Sustainability 2021, 13, 9613. [CrossRef]

54. Khan, H.; Soudagar, M.E.M.; Kumar, R.H.; Safaei, M.R.; Farooq, M.; Khidmatgar, A.; Banapurmath, N.R.; Farade, R.A.; Abbas, M.M.; Afzal, A. Effect of nano-graphene oxide and n-butanol fuel additives blended with diesel—Nigella sativa biodiesel fuel emulsion on diesel engine characteristics. Symmetry 2020, 12, 961. [CrossRef]

55. Barreta, L.G.; Lacava, P.T.; Carinhana, D. Study of the influence of biodiesel in soot emissions of diesel laminar diffusion flames. J. Braz. Chem. Soc. 2017, 28, 1384-1388.

56. Banapurmath, N.R.; Soudagar, M.E.; Ganachari, S.V.; Kulkarni, P.S.; Kumar, N.K.; Yaliwal, V. An exhaustive study on the use of Jatropha based biodiesel for modern diesel engine applications. In Biodiesel Fuels Based on Edible and Nonedible Feedstocks, Wastes, and Algae; CRC Press: Boca Raton, FL, USA, 2021; pp. 541-559.

57. Krishnakumar, S.; Khan, T.M.Y.; Rajashekhar, C.R.; Soudagar, M.E.; Afzal, A.; Elfasakhany, A. Influence of Graphene Nano Particles and Antioxidants with Waste Cooking Oil Biodiesel and Diesel Blends on Engine Performance and Emissions. Energies 2021, 14, 4306. [CrossRef]

58. Venu, H.; Raju, V.D.; Lingesan, S.; Soudagar, M.E.M. Influence of $\mathrm{Al}_{2} \mathrm{O}_{3}$ nano additives in ternary fuel (diesel-biodiesel-ethanol) blends operated in a single cylinder diesel engine: Performance, Combustion and Emission Characteristics. Energy 2021, 215, 119091. [CrossRef]

59. Mujtaba, M.; Cho, H.M.; Masjuki, H.; Kalam, M.; Farooq, M.; Soudagar, M.E.M.; Gul, M.; Ahmed, W.; Afzal, A.; Bashir, S. Effect of alcoholic and nano-particles additives on tribological properties of diesel-palm-sesame-biodiesel blends. Energy Rep. 2021, 7, 1162-1171. [CrossRef]

60. Soudagar, M.E.M.; Banapurmath, N.R.; Afzal, A.; Hossain, N.; Abbas, M.M.; Haniffa, M.A.C.M.; Naik, B.; Ahmed, W.; Nizamuddin, S.; Mubarak, N.M. Study of diesel engine characteristics by adding nanosized zinc oxide and diethyl ether additives in Mahua biodiesel-diesel fuel blend. Sci. Rep. 2020, 10, 15326. [CrossRef] [PubMed]

61. Jeshvaghani, H.S.; Fallahipanah, M.; Gahruei, M.H.; Chen, L. Performance analysis of Diesel engines fueled by biodiesel blends via thermodynamic simulation of an air-standard Diesel cycle. Int. J. Environ. Sci. Technol. 2014, 11, 139-148. [CrossRef]

62. Patil, S. Thermodynamic modelling for performance analysis of compression ignition engine fuelled with biodiesel and its blends with diesel. Int. J. Recent Technol. Eng. 2013, 1, 134-138.

63. Žvar Baškovič, U.; Vihar, R.; Seljak, T.; Katrašnik, T. Feasibility analysis of $100 \%$ tire pyrolysis oil in a common rail Diesel engine. Energy 2017, 137, 980-990. [CrossRef]

64. Vélez Godiño, J.A.; Torres García, M.; Jiménez-Espadafor Aguilar, F.J. Experimental analysis of late direct injection combustion mode in a compression-ignition engine fuelled with biodiesel/diesel blends. Energy 2021, 239, 121895. [CrossRef]

65. Pastor, J.V.; Olmeda, P.; Martín, J.; Lewiski, F. Methodology for Optical Engine Characterization by Means of the Combination of Experimental and Modeling Techniques. Appl. Sci. 2018, 8, 2571. [CrossRef] 